\title{
Crystal Structure and Infrared Spectrum of Anhydrous Guanidinium Copper(II) Carbonate
}

By Jeffrey C. Dyason and Peter C. Healy, School of Science, Griffith University, Nathan, Queensland, 4111, Australia

Brian W. Skelton and Allan H. White, Department of Chemistry, University of Western Australia, Nedlands, Western Australia, 6009, Australia

The crystal structure of the title compound, $\left[\mathrm{CN}_{3} \mathrm{H}_{6}\right]_{2}\left[\mathrm{Cu}\left(\mathrm{CO}_{3}\right)_{2}\right]$, has been determined and shown to contain a new form of the $\left[\left\{\mathrm{Cu}^{\mathrm{II}}\left(\mathrm{CO}_{3}\right)_{2}\right\}_{\infty}\right]$ polymer, the carbonate disposition being correlated with observed perturbations in the vibrational spectrum.

THE interaction of the carbonate anion, $\mathrm{CO}_{3}{ }^{2-}$, with copper(II) results in a wide range of solid-state complexes in which the carbonate group acts as a multidentate chelating or bridging ligand. ${ }^{1-8}$ We have been investigating complexes of the type $\mathrm{M}_{2}\left[\mathrm{Cu}\left(\mathrm{CO}_{3}\right)_{2}\right]$ where the carbonate acts purely as a bidentate bridging ligand to the copper atom and to date have reported on the structural, magnetic, and spectroscopic properties of the sodium, $\mathrm{Na}_{2}\left[\mathrm{Cu}\left(\mathrm{CO}_{3}\right)_{2}\right]$, and potassium, $\mathrm{K}_{2}\left[\mathrm{Cu}\left(\mathrm{CO}_{3}\right)_{2}\right]$, salts of the series. ${ }^{7-9}$ In this note we report the results of an $X$-ray crystallographic and i.r. spectroscopic analysis of $\left[\mathrm{CN}_{3} \mathrm{H}_{6}\right]_{2}\left[\mathrm{Cu}\left(\mathrm{CO}_{3}\right)_{2}\right]$ where $\mathrm{CN}_{3} \mathrm{H}_{6}{ }^{+}$is the guanidinium ion. Immediate conclusions to be drawn from the results are that the guanidinium cation is not co-ordinated to the copper(II) ion as previously suggested, ${ }^{10}$ but that the introduction of this cation leads to significant structural changes in the $\left[\mathrm{Cu}\left(\mathrm{CO}_{3}\right)_{2}\right]^{2-}$ anionic lattice.

\section{EXPERIMENTAL}

The complex was prepared in a manner similar to that previously described. ${ }^{11}$ Infrared spectra were recorded at room temperature on a Perkin-Elmer 621 grating i.r. spectrophotometer; samples were prepared as potassium bromide discs. The spectral data between 400 and 1800 $\mathrm{cm}^{-1}$ for the sodium, potassium, and guanidinium salts are recorded in Table 1 . The $1800-4000 \mathrm{~cm}^{-1}$ region con-

\section{TABLE 1}

Infrared spectral bands $\left(\mathrm{cm}^{-1}\right)$ and assignments for complexes of the type $\mathrm{M}_{2}\left[\mathrm{Cu}\left(\mathrm{CO}_{3}\right)_{2}\right]$

\begin{tabular}{|c|c|c|c|}
\hline \multirow[t]{2}{*}{$\mathrm{Na}_{2}\left[\mathrm{Cu}\left(\mathrm{CO}_{3}\right)_{2}\right]$} & \multirow[t]{2}{*}{$\mathrm{K}_{2}\left[\mathrm{Cu}\left(\mathrm{CO}_{3}\right)_{2}\right]$} & \multicolumn{2}{|c|}{$\left[\mathrm{CN}_{3} \mathrm{H}_{6}\right]_{2}\left[\mathrm{Cu}\left(\mathrm{CO}_{3}\right)_{2}\right]$ Assignments } \\
\hline & & $\begin{array}{l}1685 \\
1651\end{array}$ & \} $-\mathrm{N}$ Stretching \\
\hline 1506 & $\begin{array}{l}1548 \\
1504\end{array}$ & 1505 & $\mathrm{C}-\mathrm{O}$ Stretching \\
\hline $\begin{array}{l}1360 \\
1360\end{array}$ & $1350-1300$ & 1321 & -0 solietcining \\
\hline 1063 & 1066 & 1057 & $\mathrm{C}-\mathrm{O}$ Stretching \\
\hline 876 & 876 & & Out_of-nlane \\
\hline 853 & 856 & 850 & Out-or-plane \\
\hline 833 & 837 & 832 & \\
\hline 750 & 743 & 740 & $\mathrm{O}-\mathrm{C}-\mathrm{O}$ Bend \\
\hline 690 & 675 & 699 & C- C Dena \\
\hline & & 539 & $\mathrm{~N}-\mathrm{C}-\mathrm{N}$ Bend \\
\hline $\begin{array}{l}416 \\
400\end{array}$ & 416 & & $\begin{array}{l}\mathrm{Cu}-\mathrm{O} \\
\text { Stretching }\end{array}$ \\
\hline
\end{tabular}

tained only the $\mathrm{N}-\mathrm{H}$ stretching frequencies of the guanidinium cation and a number of weak, indistinct combination and overtone bands.

Crystallography.-Crystal data. $\quad \mathrm{C}_{4} \mathrm{H}_{12} \mathrm{CuN}_{6} \mathrm{O}_{6}, \quad M=$ 303.7, Tetragonal, space group $P \overline{4} n 2\left(D_{2 d}{ }^{8}\right.$, no. 118$), a=$ $9.068(2), c=12.583(3) \AA, U=1034.6(5) \AA^{3}, D_{\mathrm{m}}=1.94(1)$ $\mathrm{g} \mathrm{cm}^{-3}, Z=8, D_{\mathrm{c}}=1.96 \mathrm{~g} \mathrm{~cm}^{-3}, F(000)=1240$, monochromatic Mo- $K_{\alpha}$ radiation, $\lambda=0.7106_{9} \AA$, specimen size $0.36 \times 0.36 \times 0.45 \mathrm{~mm}, \mu_{\mathrm{Mo}}=21.2 \mathrm{~cm}^{-1}, T=295(1) \mathrm{K}$.

Structure determination. A unique data set was measured to $2 \theta_{\max }=90^{\circ}$ using a Syntex $P 2_{1}$ four-circle diffractometer in conventional $\theta \ldots 2 \theta$ scan mode, yielding 2340 independent reflections; of these 1356 with $I>3 \sigma(I)$ were considered observed and used in the structure solution and refinement after correction for absorption. Non-hydrogen-atom parameters $\left(x, y, z, U_{i j}\right)$ were refined using full-matrix leastsquares methods; hydrogen atoms were observed in dif-

TABLE 2

\begin{tabular}{|c|c|c|c|}
\hline Atom & $x$ & $y$ & $z$ \\
\hline $\mathrm{Cu}(1)$ & $0.5000(-)$ & $0.5000(-)$ & $0.5000(-)$ \\
\hline $\mathrm{Cu}(2)$ & $0.5000(-)$ & $1.0000(-)$ & $0.2500(-)$ \\
\hline \multicolumn{4}{|c|}{ Guanidinium cation } \\
\hline$N(1)$ & $0.3258(5)$ & $0.5818(4)$ & $0.1916(3)$ \\
\hline $\mathrm{H}(\mathbf{1} \mathrm{A})$ & $0.378(-)$ & $0.532(-)$ & $0.248(-)$ \\
\hline $\mathrm{H}(\mathrm{IB})$ & $0.332(-)$ & $0.686(-)$ & $0.187(-)$ \\
\hline $\mathrm{N}(2)$ & $0.1761(5)$ & $0.5740(4)$ & $0.0463(3)$ \\
\hline $\mathrm{H}(2 \mathrm{~A})$ & $0.119(-)^{\prime}$ & $0.520(-)$ & $-0.005(-)$ \\
\hline $\mathrm{H}(2 \mathrm{~B})$ & $0.180(-)$ & $0.679(-)$ & $0.040(-)$ \\
\hline $\mathrm{N}(3)$ & $0.2416(5)$ & $0.3617(4)$ & $0.130 \mathrm{l}(3)$ \\
\hline $\mathrm{H}(3 \mathrm{~A})$ & $0.185(-)$ & $0.306(-)$ & $0.080(-)$ \\
\hline $\mathrm{H}(3 \mathrm{~B})$ & $0.293(-)$ & $0.311(-)$ & $0.185(-)$ \\
\hline $\mathrm{C}$ & $0.2490(7)$ & $0.5056(4)$ & $0.1222(5)$ \\
\hline \multicolumn{4}{|c|}{ Carbonate anion } \\
\hline $\mathrm{C}$ & $0.4592(3)$ & $0.7564(4)$ & $0.3806(3)$ \\
\hline $\mathrm{O}(1)$ & $0.4013(3)$ & $0.8857(3)$ & $0.3624(2)$ \\
\hline $\mathrm{O}(2)$ & $0.4032(3)$ & $0.6850(3)$ & $0.4611(2)$ \\
\hline $\mathrm{O}(3)$ & $0.5596(3)$ & $0.7032(3)$ & $0.3244(2)$ \\
\hline
\end{tabular}

ference maps and improved to trigonal positions and constrained in $(x, y, z, U), U_{\mathrm{H}}$ being set at $1.25 \bar{U}_{i i}(\mathrm{~N}) .^{*}$

Residuals at convergence were $\left(R, R^{\prime}, S\right) 0.042,0.059,1.75$; $R$ and $R^{\prime}$ remained unchanged after change of chirality. Neutral atom scattering factors were employed, those for the

* It is hoped that hydrogen parameters will shortly be available from a neutron diffraction study, to be used in conjunction with a more extensive $X$-ray data set in an attempt to define the nature of the electron distributions about the copper atoms. 
non-hydrogen atoms being corrected for anomalous dispersion $\left(f^{\prime}, f^{\prime \prime}\right) .^{12}$ Computation was carried out using the ' $X$-RAY ' 76 ' program system ${ }^{13}$ implemented on a PerkinElmer 8/32 computer by S. R. Hall. Material deposited as Supplementary Publication No. SUP 23065 (13 pp. $) \dagger$ comprises structure factor amplitudes, thermal parameters, and hydrogen-atom geometries, and a projection of the cell contents down $c$, together with the spectra of Table 1. Atomic co-ordinates are given in Table 2 and the Figure shows the unit-cell contents projected down $a$.

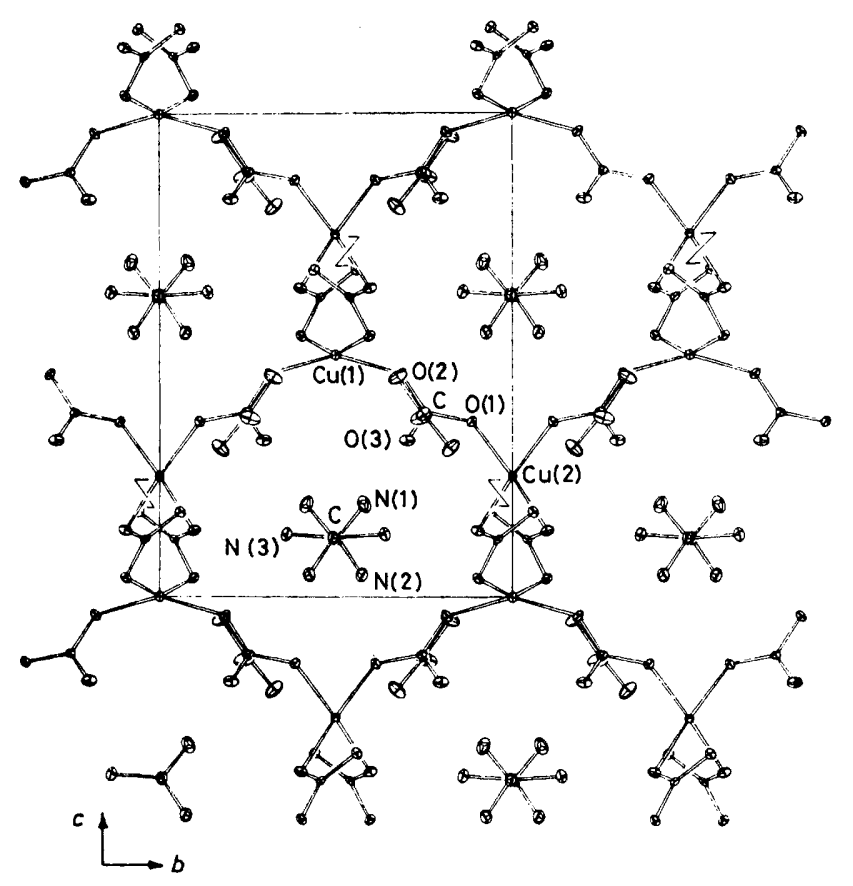

Unit-cell contents projected down $a$; non-hydrogen atoms are shown with $20 \%$ thermal ellipsoids

\section{RESULTS AND DISCUSSION}

The structure of the present complex is best analysed in comparison with the analogous members of this series of complexes. The structure of $\mathrm{Na}_{2}\left[\mathrm{Cu}\left(\mathrm{CO}_{3}\right)_{2}\right]$ comprises a planar array of copper atoms at the inversion centres of a $P 2_{1} / a$ unit cell, linked in an infinite polymeric sheet by bidentate bridging carbonates, with the sodium ions dispersed between the $\left[\mathrm{Cu}\left(\mathrm{CO}_{3}\right)_{2}\right]_{\infty}$ sheets. The carbonate groups in this complex lie nearly perpendicular to the plane of the copper atoms (dihedral angle $84^{\circ}$ ). The central carbon atom of each carbonate is situated nearly on the glide planes at $y=\frac{1}{4}, y=\frac{3}{4}$, leading to a carbonate-carbonate separation of $c a .3 .1 \AA$. The inversion centre on the copper atom requires the carbonates along $y=\frac{1}{4}$ and $y=\frac{3}{4}$ to be directed above and below the copper plane respectively.

The symmetry of the unit cell of $\mathrm{K}_{2}\left[\mathrm{Cu}\left(\mathrm{CO}_{3}\right)_{2}\right]$ is higher and non-centrosymmetric, being $F d d 2$, with the copper atoms located on two-fold axes, and with a less exact square-planar environment of oxygen atoms, drawn from the bidentate bridging carbonate groups.

† For details see Notices to Authors No. 7, J. Chem. Soc., Dalton Trans., 1980, Index issue.
The two-fold axes on the copper atoms require the nonbonded oxygens of the carbonates situated trans to the copper to be directed either above or below the plane perpendicular to the $\mathrm{CuO}_{4}$ plane. Further symmetry arising from the crystallographic glide planes constrains all four carbonate groups to be directed above the $\mathrm{CuO}_{4}$ plane. These symmetry requirements lead to a packing arrangement of the carbonates similar to the sodium salt, with an interplanar distance of $c a .3 .2 \AA$. However, the changed conformation of the $\left[\mathrm{Cu}\left(\mathrm{CO}_{3}\right)_{2}\right]_{\infty}$ planes leads to a three-dimensional polymeric system rather than the layer type structure found in the sodium salt.

In the present case, the cell symmetry is found to be tetragonal and also non-centrosymmetric, $P \overline{4} n 2$. There are two independent copper atoms in the structure. One lies on a site of 222 symmetry $\left(\frac{1}{2}, 0, \frac{1}{4}\right)[\mathrm{Cu}(2)]$, while the other $[\mathrm{Cu}(1)]$ is on a site of $\overline{4}$ symmetry at $\left(\frac{1}{2}, \frac{1}{2}, \frac{1}{2}\right)$. In both cases, the environment of the copper atom comprises four oxygen atoms drawn from nearby carbonate groups, only one oxygen atom about each copper atom being independent, as the remaining three are generated from it by the site symmetry. In the case of neither copper atom can the environment be said to be square planar although the four-fold co-ordination about each copper must be regarded as derivative of that archetype. For $\mathrm{Cu}(1)$, a pseudo-tetrahedral distortion is superimposed, the trans angle in the co-ordination sphere being $151.0(1)^{\circ}$, while, for $\mathrm{Cu}(2)$, the distortion is perhaps better described as rhombic although again a non-linear 'trans' angle is found $\left[174.2(1)^{\circ}\right]$. Both $\mathrm{Cu}-\mathrm{O}$ distances are longer than the values of $1.934(2), 1.936(2) \AA$ found in the potassium salt. As in $\mathrm{K}_{2}\left[\mathrm{Cu}\left(\mathrm{CO}_{3}\right)_{2}\right]$, the copper atoms are linked into a three-dimensional polymer by the bidentate carbonate groups. However, in this structure, the symmetry of the unit cell requires the carbonate groups to be alternately directed above and below the $\mathrm{CuO}_{4}$ planes. This requirement destroys the layer structure of the carbonates found in the other two systems and doubles the closest parallel carbonate-carbonate contact distance to $c a .6 .2 \AA$. The structure accommodates the guanidinium counter ions in large tunnels running parallel to $a$ and $b$.

As in previous examples, the carbonate ion geometry is unsymmetrical, $\mathrm{C}-\mathrm{O}(3)$, the ' unco-ordinated 'bond being shorter $[1.249(5) \AA]$ than the other two 'co-ordinated' bonds and opposed to the smallest $\mathrm{O}-\mathrm{C}-\mathrm{O}$ angle $[\mathrm{O}(1)-\mathrm{C}-$ $\left.\mathrm{O}(2), 115.2(3)^{\circ}\right]$. The 'isoelectronic' guanidinium cation, by contrast, although possessing no intrinsic crystallographic symmetry is very regular in its geometry (Table 3). The regular geometry observed here contrasts with the distortions observed in the structure of guanidinium carbonate ${ }^{\mathbf{1 4}}$ where strong hydrogen-bonding interactions lead to considerable variations in the $\mathrm{C}-\mathrm{N}$ and $\mathrm{C}-\mathrm{O}$ distances.

With regards to the $\mathrm{CO}_{3}{ }^{2-}$ vibrational modes, the i.r. spectra of the three complexes are very similar. Six strong absorption bands are observed at ca. 675, 740, $850,1060,1330$, and $1500 \mathrm{~cm}^{-1}$, which can be assigned to the six expected fundamental $\mathrm{CO}_{3}{ }^{2-}$ vibrational modes. 
TABLE 3

Interatomic distances $(\AA)$ and angles $\left({ }^{\circ}\right)$ (non-hydrogen atoms)

(a) Copper environments ${ }^{a}$

$\begin{array}{lr}\mathrm{Cu}(1)-\mathrm{O}(2) & 1.956(3) \\ \mathrm{O}(2)-\mathrm{Cu}(1)-\mathrm{O}\left(2^{\mathrm{I}}\right) & 151.0(1) \\ \mathrm{O}(2)-\mathrm{Cu}(1)-\mathrm{O}\left(2^{\mathrm{II}}\right) & 93.6(1) \\ \mathrm{Cu}(2)-\mathrm{O}(1) & 1.968(3) \\ \mathrm{O}(1)-\mathrm{Cu}(2)-\mathrm{O}\left(1^{\mathrm{III}}\right) & 88.2(1) \\ \mathrm{O}(1)-\mathrm{Cu}(2)-\mathrm{O}\left(1^{\mathrm{IV}}\right) & 92.1(1) \\ \mathrm{O}(1)-\mathrm{Cu}(2)-\mathrm{O}\left(1^{\mathrm{V}}\right) & 174.2(1)\end{array}$

(There are no other $\mathrm{Cu} \cdots$ O contacts $<2.9 \AA$ )

(b) Carbonate ion ${ }^{b}$

$\begin{array}{ll}\mathrm{C}-\mathrm{O}(1) & 1.306(5) \\ \mathrm{C}-\mathrm{O}(2) & 1.305(5) \\ \mathrm{C}-\mathrm{O}(3) & 1.249(5) \\ \mathrm{O}(1)-\mathrm{C}-\mathrm{O}(2) & 115.2(3) \\ \mathrm{O}(1)-\mathrm{C}-\mathrm{O}(3) & 122.8(4) \\ \mathrm{O}(2)-\mathrm{C}-\mathrm{O}(3) & 122.1(3) \\ \mathrm{Cu}(1)-\mathrm{O}(2)-\mathrm{C} & 116.4(2) \\ \mathrm{Cu}(2)-\mathrm{O}(1)-\mathrm{C} & 114.6(2)\end{array}$

(c) Guanidinium cation

$\begin{array}{ll}\mathrm{C}-\mathrm{N}(1) & 1.313(7) \\ \mathrm{C}-\mathrm{N}(2) & 1.317(7) \\ \mathrm{C}-\mathrm{N}(3) & 1.311(5) \\ \mathrm{N}(1)-\mathrm{C}-\mathrm{N}(2) & 120.1(4) \\ \mathrm{N}(1)-\mathrm{C}-\mathrm{N}(3) & 120.0(5) \\ \mathrm{N}(2)-\mathrm{C}-\mathrm{N}(3) & 119.9(5)\end{array}$

a Transformations: I $1-x, 1-y, z$; II $x, 1-y, 1-z$; III $1-x, 2-y, z ;$ IV $x+\frac{1}{2}, y-\frac{1}{2}, \frac{1}{2}-z ;$ V $\frac{3}{2}-x$, $\frac{3}{2}-y, \frac{1}{2}-z . \quad{ }^{b}$ Atom deviations from a least-squares plane through $\mathrm{CO}_{3}$ are $[\mathrm{C}, \mathrm{O}(1,2,3), \mathrm{Cu}(1), \mathrm{Cu}(2)]: 0.004,-0.002$, $-0.002,-0.002,0.192,0.189 \AA$. For the guanidinium $\mathrm{CN}_{3}$ plane $\sigma$ (defining atoms) is $0.006 \AA$, with no deviation $>0.009 \AA$.

Of the three complexes, however, the spectrum of the guanidinium complex is the least complex. No carbonate bands are split and all are relatively sharp. In contrast, the sodium and potassium salts exhibit very sharp high-frequency bands on the side of that at $\mathbf{8 5 0}$ $\mathrm{cm}^{-1}$, and broad bands, split in the potassium salt, in the $1300-1500 \mathrm{~cm}^{-1}$ region.

While it is not possible in these complex systems to relate structural and spectroscopic features in a simple manner, it may be significant that, in the guanidinium complex, carbonate-carbonate interactions are minimal. Conversely, in the potassium salt and sodium salts the packing of the carbonate groups might be expected to give rise to intermolecular interactions of the type observed for simple ionic carbonates with the aragonite structure.

Splitting of the out-of-plane $v_{2}$ band has been observed and discussed for many simple carbonate systems. ${ }^{15-18}$ The non-degeneracy of the vibration in the isolated $\mathrm{CO}_{3}{ }^{2-}$ ion has led to explanations of the splitting in terms of either interionic carbonate-carbonate interactions or the presence of ${ }^{13} \mathrm{CO}_{3}{ }^{2-}$. A study of spectra of the present complexes together with reported spectra of other carbonates points to the existence of two extra bands. The first, a low-intensity shoulder on the low-frequency side of the main $v_{2}$ band, appears in all carbonates studied and the assignments to a vibration due to ${ }^{13} \mathrm{CO}_{3}{ }^{2-}$ seem reasonable. The second very sharp, medium-intensity band is observed only in those compounds where the carbonate groups are parallel and separated by $<3.5 \AA$. This observation has led to the conclusion that the band results from a coupling of $\nu_{2}$ with intermolecular carbonate-carbonate crystal lattice vibrations. The mechanisms of such interactions have not however been fully analysed. In the present series of complexes it is of considerable interest to note the sharp band is observed as a high-frequency component of $v_{2}$ in contrast to the spectra of aragonite type crystals, where the band is invariably observed as a low-frequency component.

We gratefully acknowledge a grant from the Australian Research Grants Committee in support of this work.

[0/1852 Received, 2nd December, 1980]

\section{REFERENCES}

1 M. R. Churchill, G. Davies, M. A. El-Sayed, M. F. El-Shazly, J. P. Hutchinson, M. W. Rupich, and K. O. Watkins, Inorg. Chem., 1979, 18, 2296.

2 A. R. Davis, F. W. B. Einstein, N. F. Curtis, and J. W. L. Martin, J. Am. Chem. Soc., 1978, 100,6258; A. R. Davis and F. W. B. Einstein, Inorg. Chem., 1980, 19, 1203.

3 P. Süsse, Acta Crystallogr., 1967, 22, 146; F. Zigan, W. Joswig, H. D. Schuster, and S. A. Mason, Z. Kristallogr, 1977, 145, 412.

G. Gattow and J. Zemann, Acta Crystallogr., 1958, 11, 866.

5 P. D. Brotherton and A. H. White, J. Chem. Soc., Dalton Trans., 1973, 2338; R. L. Harlow and S. H. Simonsen, Acta Crystallogr., Sect. B, 1975, 31, 1313.

6 M. H. Meyer, P. Singh, W. E. Hatfield, and D. J. Hodgson, Acta Crystallogr., Sect. B, 1972, 28, 1607.

7 P. C. Healy and A. H. White, J. Chem. Soc., Dalton Trans., $1972,1913$.

8 A. Farrand, A. K. Gregson, B. W. Skelton, and A. H. White Aust. J. Chem., 1980, 33, 431; B. N. Figgis, P. A. Reynolds, A. H. White, and G. A. Williams, J. Chem. Soc., Dalton Trans., 1981, 371 .

9 A. K. Gregson and P. C. Healy, Inovg. Chem., 1978, 17, 2969.

10 D. S. Shlyapnikov and E. K. Shtern, Russ. J. Inorg. Chem. (Engl. Transl.), 1978, 23, 871 .

${ }_{11}$ A. K. Sengupta and A. K. Nandi, J. Inorg. Nucl. Chem., $1974,36,2479$.

12 D. T. Cromer and J. B. Mann, Acta Crystallogr., Sect. A, 1968, 24, 321; D. T. Cromer and D. Liberman, J. Chem. Phys., $1970,53,1891$.

13 The $X$-Ray System, Version of March 1976, Technical Report TR-446, Computer Science Center, University of Maryland, U.S.A.

${ }_{14}$ J. M. Adams and R. W. H. Small, Acta Crystallogr., Sect. B, $1974,30,2191$.

${ }_{15}$ J. C. Decius, J. Chem. Phys., 1955, 23, 1290.

16 C. J. H. Schutte and K. Buijs, Nature, 1961, 192, 351

17 W. Sterzel and E. Chorinsky, Spectrochim. Acta, Part A, $1968,24,353$

18 J. A. Goldsmith and S. D. Ross, Spectrochim. Acta, Part A, $1968,24,993$ 